\title{
絹フィブロインからなる弱電解質両性荷電膜に打ける膜電位
}

\author{
東京工業大学工学部 陳 建勇 ·谷岡 明彦*1 \\ 物質工学工業技術研究所 箕浦 憲彦*2
}

\section{Membrane Potential of Weak Amphoteric Polymer Membrane Composed of Silk Fibroin}

\section{Chen Jianyong, Akihiko Tanioka*1, and Norihiko Minoura*2}

Department of Organic and Polymeric Materials. Tokyo Institute of Technology, Tokyo, 152 Japan

${ }^{* 2}$ National Institute of Materials and Chemical Research, 1-1, Higasi, Tsukuba, Ibaraki, 305 Japan

\begin{abstract}
Silk fibroin membrane is the amphoteric ion exchange membrane with the weak acid and base which are composed of amino and carboxyl groups, respectively. In this study ion transport phenomena were investigated using Teorell-Meyers-Sievers (TMS) theory. Membrane potential was measured for $\mathrm{KCl}$, $\mathrm{K}_{2} \mathrm{SO}_{4}, \mathrm{~K}_{2} \mathrm{HPO}_{4}, \mathrm{MgCl}_{2}, \mathrm{CaCl}_{2}$, and $\mathrm{MgSO}_{4}$ aqueous solution. The effective charge density $\left(\mathrm{QC}_{\mathrm{x}}\right)$ and ion mobility ratio of anion to cation $\left(\omega_{-} / \omega_{+}\right)$in the membrane were calculated by applying TMS theory to experimental results. $\mathrm{QC}_{\mathrm{x}}$ was $0.015 \mathrm{~mol} / \mathrm{L}$. which was one-nineteenth times smaller than that calculated from the data of amino acid content in silk fibroin. $\omega_{-} / \omega_{+}$of $\mathrm{KCl}, \mathrm{CaCl}_{2}$ and $\mathrm{MgCl}_{2}$ in the membrane were larger than that in water, and $\omega_{-} / \omega_{+}$of $\mathrm{K}_{2} \mathrm{SO}_{4}, \mathrm{~K}_{2} \mathrm{HPO}_{4}$ and $\mathrm{MgSO}_{4}$ were smaller than that in water.
\end{abstract}

(Received April 2, 1993)

\section{1. 序論}

絹フイプロイン膜は家虫䅌糸から作成され、弱電解質 イオン交換基を有するポリアミ，酸膜である。グル夕ミ ン酸やアスパラギン酸などの酸性アミノ酸とリジンやア ルギニンやヒスチジンなどの㻥基性アミノ酸を同時に有 古ることから雨性荷電膜とも考之られることがでさる。 阔性荷電膜のうち强電解啠イオン交換基を持つものにつ いてはすでに君塚ら[1]や山内ら[2]により輸送係数、 膜電位，圧透析等の测定が行加れ，非平衡の熱力学に基 つく解析がなされている。一方弱電解質雨性荷電膜に関 しては生体膜の基礎研究としての重要性や圧透析等の可 能性が指摘されている。しかしながら，固定荷電基のイ オン交換容量がカチオンとアニオンとも $\mathrm{pH} に$ 依存する ことなど取扱いが非常に複雑なために体系的な議論が少 ない。

一方絹フィブロイン膜- $\mathrm{NaCl}$ 采において中性付近で膜 電位測定を行うとカチオン交換膜と同様の挙動をするこ とが報告されている[3]。またフィブロイン膜にスチレ

* To whow correspondence should be addressed.
ンをグラフトするとグラフト率の増加につれて膜電位が 增加することが報告されている[4]。そこで本研究では 絹フィプロイン膜における各種金属塩溶液中での膜電位 の测定を行い, Teorell-Meyer-Sievers (TMS)の膜電位に 関する理論 $[5][6$ ]を適用して、弱電解質再性荷電膜に おけるイオン移動度や膜の有效荷電密度について論し る。ここでの取扱いは君榢らの方法と異なるが荷電密度 等絹フィブロイン膜固有の内部パラメータを使用するた め圧透析膜や人工透析膜としての利用を考える上で有用 であると考えられる。

\section{2. 理 論 (7)}

膜の雨側における電解鲑溶液の濃度差により生じる膜 電位 $\Delta \phi は ，$ 膜と溶液の界面で発生するドナン電位と膜 内でのイオンの搪散より生しる搪散電位 $\Delta$ 中 diff とから なっている(TMS の理諭)。

$$
\begin{aligned}
\Delta \phi & =\Delta \phi_{\mathrm{D} 0}+\Delta \phi_{\mathrm{Da}}+\Delta \phi_{\text {diff }} \\
& =\Delta \phi_{\mathrm{D}}+\Delta \phi_{\text {diff }}
\end{aligned}
$$

$こ こ て ゙ \Delta \phi_{\mathrm{D} 0}, \Delta \phi_{\mathrm{Dd}}$ はそれぞれ膜と高嶩度側及び低 濃度側溶液との界面で発生するドナン電位であり， $\Delta \phi_{\mathrm{D}}$ $=\Delta \phi_{\mathrm{D} 0}+\Delta \phi_{\mathrm{Dd}}$ の関係が成り立つ。 
一般的には取り极いを䉮単にするために KC 1 等の】 - 1 型電船啠に関して論じられることが多い。本研究で は $\mathrm{MgCl}_{2}, \mathrm{CaCl}_{2}, \mathrm{~K}_{2} \mathrm{SO}_{4}, \mathrm{~K}_{2} \mathrm{HPO}_{4}, \mathrm{MgSO}_{4}$ 等の 2 洒化 オンを含む系については取り扱う。まず $\mathrm{KCl}, \mathrm{MgCl}_{2}$, $\mathrm{CaCl}_{2}, \mathrm{~K}_{2} \mathrm{SO}_{4}, \mathrm{~K}_{2} \mathrm{HPO}_{4}$ に関しては一般化して, $\mathrm{B}_{\mathrm{n}}{ }^{\mathrm{m}+}$ $\mathrm{A}_{n \mathrm{n}}{ }^{\mathrm{n}-}$ (イオン価数 $z_{i}=+\mathrm{m},-\mathrm{n}$ )なる多価電解犋が水 相中で完全に電離していると考えると次式が成立する。

$$
\mathrm{B}_{\mathrm{n}} \mathrm{A}_{\mathrm{m}} \rightarrow \mathrm{n} \mathrm{B}^{\mathrm{m}+}+\mathrm{mA} \mathrm{A}^{\mathrm{n}^{-}}
$$

膜内の電解質濃度を $C_{j}$, 高濃度側の溶液濃度を $\mathrm{C}_{0}$, 低 濃度側の溶液濃度を $C_{d}$ とする。それぞれのアニオン及 びカチオンに対しては式 2 より $\mathrm{A}=\left(\mathrm{A}_{i}, \mathrm{~A}_{0}, \mathrm{~A}_{\mathrm{d}}\right), \mathrm{B}=$ $\left(\mathrm{B}_{1}, \mathrm{~B}_{0}, \mathrm{~B}_{\mathrm{d}}\right)$ とおくことができる。膜が筫に荷電してい るとして, 膜中の固定電偨密度 $C_{x} と お く と$, 電気的 中性条件加,

$\mathrm{m} \mathrm{B}_{\mathrm{i}}=\mathrm{n} \mathrm{A}_{\mathrm{i}}+\mathrm{C}_{\mathrm{x}}$

一方水溶液相においては

$$
\mathrm{m} \mathrm{B}_{\mathrm{h}}=\mathrm{n} \mathrm{A}_{\mathrm{h}}=\mathrm{mnC} \mathrm{C}_{\mathrm{h}}
$$

ここで $\mathrm{h}=0$ またはdとする。膜と瀖液の界面ではお 互いの電気化学ポテンシャルが等しいから外部溶㴕と膜 中の電解貿濃度との閏に

$$
\left(A_{i}\right)^{m}\left(A_{i}+\frac{C_{x}}{n}\right)^{n}-K\left(m C_{b}\right)^{m+n}=0
$$

の関係が成立する。たたし

$$
K=\left(\frac{k_{B} \gamma_{B h}}{\gamma_{B i}}\right)^{n}\left(\frac{k_{A} \gamma_{A h}}{\gamma_{A i}}\right)^{\mathrm{m}}
$$

ここで $k_{\mathrm{A}} ， \mathrm{k}_{\mathrm{B}}$ はアニオン及びカチオンの分配係数。 $\gamma_{\mathrm{Ah}}, \gamma_{\mathrm{Bh}}$ は水溶液相， $\gamma_{\mathrm{Ai}}, \gamma_{\mathrm{Bi}}$ は膜相におけるア二 オンとカチオンの活量係数である。また，MgSOは関し ては式 4 の電気的中性条件が

$$
2 B_{h}=2 A_{h}=2 C_{h}
$$

となるから式 5 は

$$
\left(A_{i}\right)^{2}\left(A_{i}+1 / 2 C_{x}\right)^{2}-K C_{0} 4=0
$$

となる。

膜の界面で発生するドナン電位は

$$
\Delta \phi_{D}=-\frac{R T}{n F} \ln \frac{A_{0} k_{A, 0} \gamma_{A, 0} \gamma_{A, j, d} A_{i, d}}{A_{d} k_{A, d} \gamma_{A, d} \gamma_{A, i, 0} A_{i, 0}}(7)
$$

となる。式 $5 ， 5$ に拈ける万程式の解を近似計算によ り求め, 式 $7 に$ に代入することによりドナン電位を求め る。坑散電位に関しては, Nernst-Planckの流束の式

$$
J_{i}=-\omega_{i} R T \frac{d c_{i}}{d x}-z_{i} F \omega_{i} C_{i} \frac{d \phi_{\text {diff }}}{d x}
$$

を㳟における濃度勾配一定及び全電流ゼロ( $1=0)$ とい う条件下で解を求めると, 次式が得られる(Henderson の式)。

$$
\Delta \phi_{\text {diff }}=-\frac{R T}{F} \frac{\sum_{i} z_{i} \omega_{i}\left(C_{i, d}-C_{i, o}\right)}{\sum_{i} z_{i}{ }^{2} \omega_{i}\left(C_{i, d}-C_{i, 0}\right)}
$$

$$
\begin{aligned}
& \times \ln \frac{\Sigma_{i} z_{i}{ }^{2} \omega_{i} C_{i, d}}{\Sigma_{i} z_{i}{ }^{2} \omega_{i} C_{i, d}} \\
& Z_{i}= \pm 1, \pm, 2, C_{i}=A_{i} \text { or } B_{i}
\end{aligned}
$$

ここでRは気体定数，Fはファラデー定数，Tは絶対温 度， $2_{\mathrm{i}}$ はイオンの洒数，

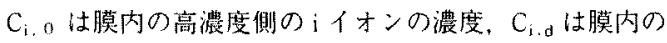
低濃度側のiインンの濃度である。

以上の結果加式7，9索式1に代入して膜電位を求 めることができる。数值解析を行うにあたり，膜におけ るイオンの分配係数や活量係数の比を 1 とおいた。した がってこのとき式 6 は $\mathrm{K}=1$ となる。

\section{3. 実験}

\section{1 試 料}

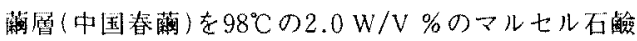
水溶液中に拈いて，50分闑精練を2回繰り这した。さら に5 $0^{\circ} \mathrm{C} 0.05 \% の \mathrm{Na}_{2} \mathrm{CO}_{3}$ 水浴液中で約 20 分間処理し. セリシンを除去した。次に約 $50^{\circ} \mathrm{C} の$ 温水中, 及び空温 の玲水で十分洗海し, 选心分離器によって脱水したあ と, $85^{\circ} \mathrm{C}$ の惿温器中で乾燥した。

1 グラムの精練綟糸(フィブロイン)を $\mathrm{CaCl}_{2}$ : $\mathrm{C}_{2} \mathrm{H}_{5} \mathrm{OH}: \mathrm{H}_{2} \mathrm{O}=1: 2: 8($ モル比)[8]の混合溶液 $100 \mathrm{~mL}$ 中にて $70^{\circ} \mathrm{C} て ゙ ， 2$ 時間溶解させた。溶解したフィブロ イン水溶液を滤過したあと，滤過液をイオン交換水によ ってセルロース半透膜により三日間透析した[9]。濃紑 したフィブロイン溶液はポリスチレンのシャーレの上に

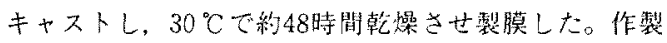
された膜の匽みは25〜40, 作成した膜を75\%×タノール中にて15分間処理した $(10)_{0}$ この処理により膜の結晶化が進み，水溶液中で不 溶化する。

\section{2 電解質溶液}

膜電位測定に使用した電解質は $1-1$ 型として KCl, 1 - 2 型として $\mathrm{K}_{2} \mathrm{SO}_{4}$ 及び $\mathrm{K}_{2} \mathrm{HPO}_{4} ， 2$ - 1 型として $\mathrm{MgCl}_{2}$ 及び $\mathrm{CaCl}_{2} ， 2-2$ 型として $\mathrm{MgSO}_{4}$ である。

\section{3 測 定}

膜電位測定：測走装置を网1に示す。左側のセルの湄

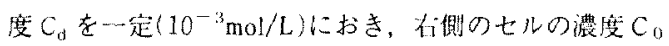

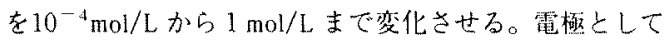
銀・塩化銀電極(TOA GST-5311C $211 \mathrm{~F} \mathrm{~S}$ ) を使用し, 測

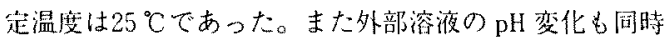

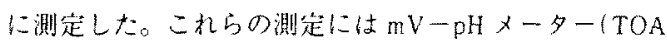
HM-20E)を使用した。 


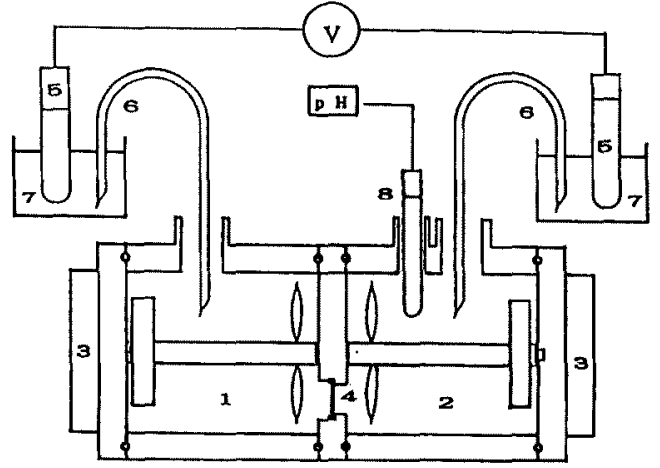

Fig. 1 Apparatus for Membrane potential measurement 1 salt solution $\left(C_{d}\right), 2$ salt solution $\left(C_{0}\right), 3$ Magnetic stir. rer, 4 Membrane, 5 Glass electrode, 6 Salt bridge, 73.3 $\mathrm{M} \mathrm{KCl}$ aqueous solution, $8 \mathrm{pH}$ electrode.
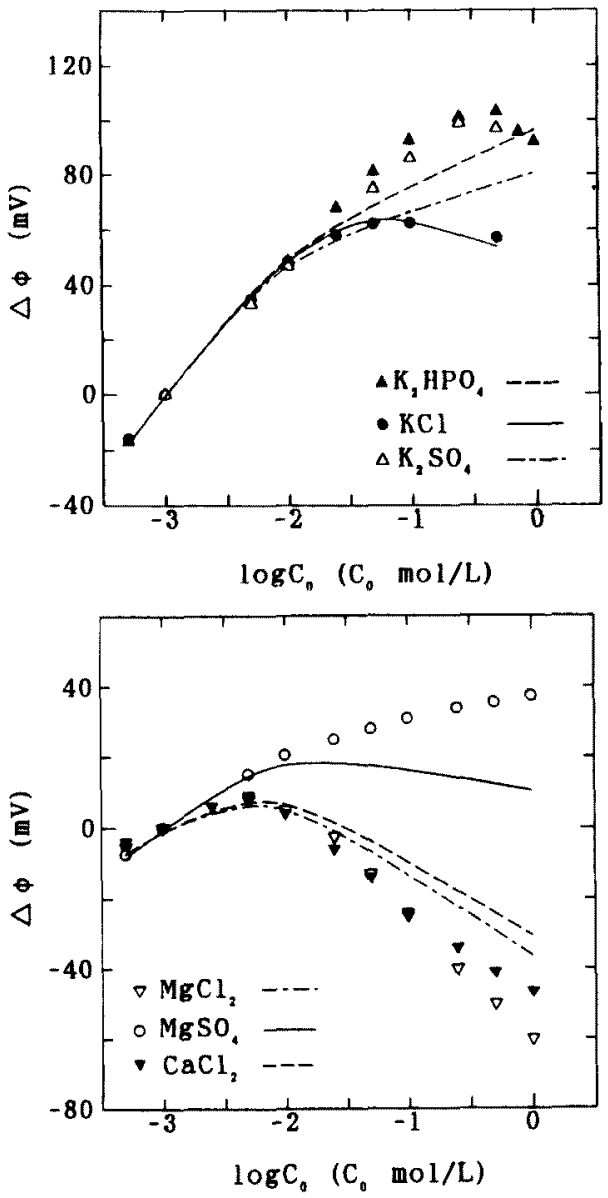

Fig. 2 a,b Membrane potential of various salt solution. Lines show the calculated results using ion mobility in water with effective charge density $\mathrm{QC}_{\mathrm{x}}=0.012$.

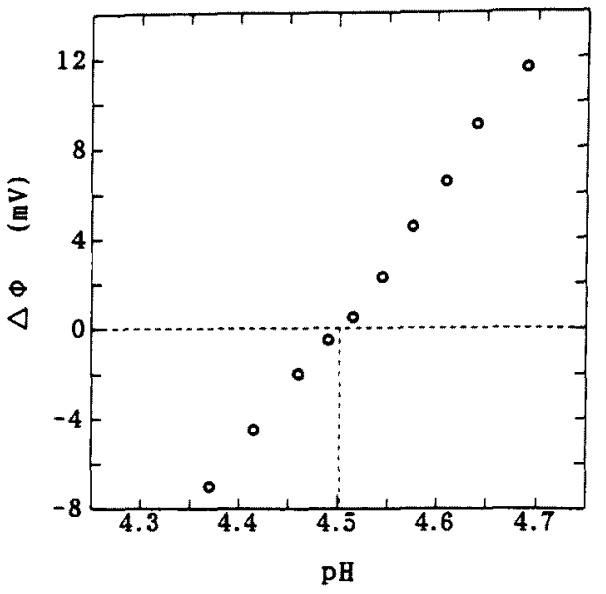

Fig. 3 Membrane potential as a function of $\mathrm{pH}$ in $\mathrm{KCl}$ and $\mathrm{HCl}$ solution.

\section{4. 粘果と考察}

\section{1 膜電位}

图 2 -a に KCl, $\mathrm{K}_{2} \mathrm{SO}_{4}, \mathrm{~K}_{2} \mathrm{HPO}_{4}$ 絹フィブロイン膜 系, 図 2-bに $\mathrm{CaCl}_{2}, \mathrm{MgCl}_{2}, \mathrm{MgSO}_{4}$ 絹フィブロイン膜 系における膜電位と右側七ルの電解質の濃度 $\mathrm{C}_{0}$ との関 係をプロットする。まず1-1 型電解質である $\mathrm{KCl}$ は, $\mathrm{C}_{0}$ が増加すると膜電位は増加し，高濃度になると減少す る。このような膜電位の傾向は一般の 1 - 1 型電解貿一負 荷電膜系でみられるものである。ところで膜の両側のセ ルにおける KCl濃度をそれぞれ0.1 mol $/ \mathrm{L} と 0.01 \mathrm{~mol} / \mathrm{L}$ に保ち，セルの雨方に $\mathrm{HCl}$ 等濃度づつ入れ，その濃度 を $10^{-5} \mathrm{~mol} / \mathrm{L}$ から $10^{-4} \mathrm{~mol} / \mathrm{L}$ まで変化させた時の膜電位 と水素イオン濃度との関係を図 3 に示す。 $\mathrm{K}^{+}$と $\mathrm{Cl}^{-}$の 水中でのイオン移動度はほほ等しく，膜中でもこの傾向 があまり大きく変化しないとすると，等電点付近では見 がけ電荷がほほゼロであるから，膜電位もほとんど無 視できると考えることができる。このことから $\mathrm{pH}=$ 4.5 付近が本絹フィブロイン膜の等電点にはほ対応して

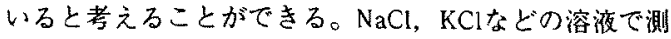
定した結果によると塩濃度にかかわらず等電点の $\mathrm{pH}$ は 約 4〜5であって(12)本测定結果と大きな椲いは見られ なかった。一方膜電位の測定中における $\mathrm{pH}$ を測定して 図 4 に示したところ, いずれの電解質を使用しても $\mathrm{pH}$ は5.5以上であった。このことは見かけ上膜が負に荷電

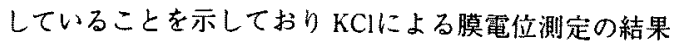
と対応している。図 $2 \mathrm{a} に \mathrm{~K}^{+}$と と $\mathrm{Cl}^{-}$の膜中の移動度の比 $\omega-/ \omega+$ が水中の值に等しい $(=1.039)$ とおいて TMSの 理論を適用し有効荷電密度 $\left(\mathrm{QC}_{\mathrm{x}}\right)$ をパラメータとして カーブフィッティングを行った[13](14]。高浪度側では 


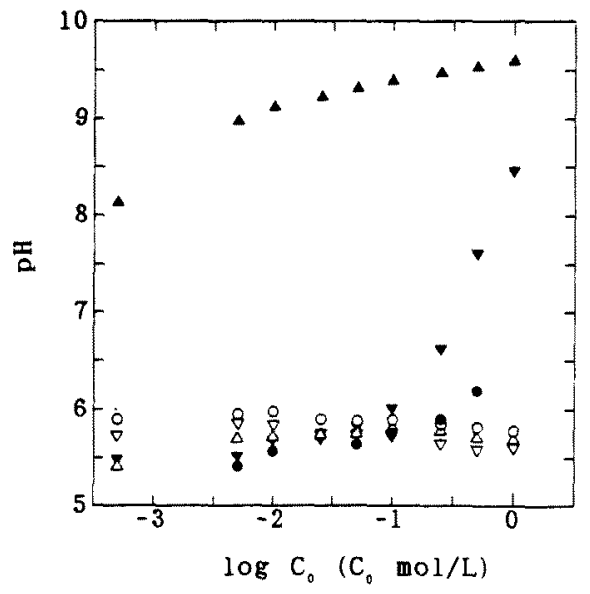

Fig. $4 \mathrm{pH}$ in external solution shown as a function of salt concentration, where is $\mathrm{KCl}, \triangle \mathrm{K}_{2} \mathrm{SO}_{4} \Delta \mathrm{K}_{2} \mathrm{HPO}_{4}$ $O \mathrm{MgSO}_{4}, \nabla \mathrm{MgCl}_{2}$ and $\nabla \mathrm{CaCl}_{2}$.
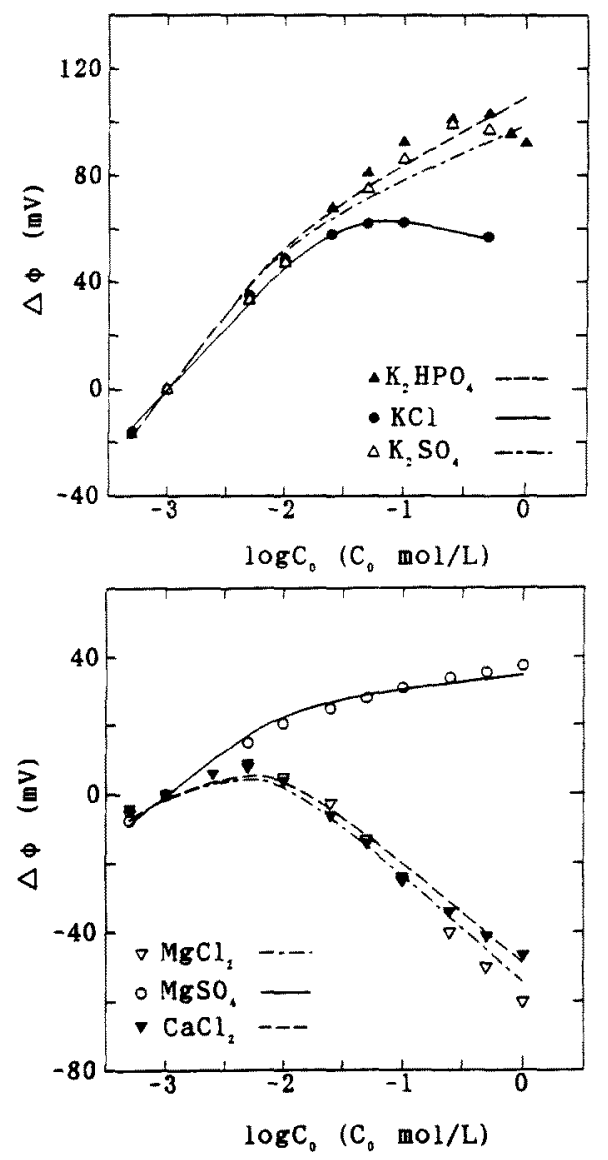

Fig. 5 a,b Membrane potential of various salt solution. Lines show the calculated results where the ion mobility was fitting parameter with $Q C_{x}=0.015 \mathrm{~mol} / \mathrm{L}$.
若干ずれるが，QC の良い一致を示した。そこで $\mathrm{K}_{2} \mathrm{HPO}_{4} ， \mathrm{~K}_{2} \mathrm{SO}_{4}$ に関する カチオンとアニオンの水中での移動度の比 $\left(\omega_{-} / \omega_{+}=\right.$ $0.388,0.525)$ と $\mathrm{KCl}$ で求めた $\mathrm{QC}_{\mathrm{x}}$ 女用いて膜電位と濃 度の関係を求め，点線及び一点鎖線で図 2 低濃度側で寒験值と計算値は良い一致を示すが高濃度側 では著しくずれた。さらに图2-bに $\mathrm{MgSO}_{4}, \mathrm{MgCl}_{2}$, $\mathrm{CaCl}_{2}$ の結果を示す。図 2-bは図 2-aと同様に $\mathrm{KCl}$ から 求めた $\mathrm{QC}_{\mathrm{x}}(=0.012 \mathrm{~mol} / \mathrm{L})$ と水中における移動度の比 $\left(\omega / \omega_{+}=1.50 ， 2.98 ， 2.70\right)$ 使用して計算した結果 である。2-2型である $\mathrm{MgSO}_{4}$ に関しては奏験値に比べ て計算值は著しく低電位側にずれた。逆に2-1型の $\mathrm{MgCl}_{2}$ と $\mathrm{CaCl}_{2}$ に関しては計算值は正の方へずれた図 2 -a，図 2 -bからアニオンが 2 洒の時は計算值が実験に 比べて負の方にずれ，カチオンが2 価の場合は正の方に ず机ることが明かとなった。次に $\mathrm{KCl}$

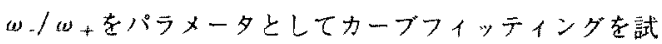
みた。この時 $\mathrm{QC}_{x}=0.015, \omega_{-} / \omega_{+}=1.240$ 時，奏験 值と計算值は最も良い一致をみた。そこで，それぞれの 塭溶液に対して $\mathrm{QC}_{\mathrm{x}}=0.015 と し て, \omega / \omega+$ をパラ メータとしてカーブフィッティングを試みた。実験及び 計算結果老图 $5 \mathrm{a}, \mathrm{b}$ に示す。高濃度側では必ずしも一致 しないが，図 $2 \mathrm{a}, \mathrm{b}$ に比べて比較的に良い一致を見た。 電解質の収着による膜の収縮や膨潤，水采イオン濃度の 变化等非常に複雑な要因が加えるためこれ以上の計算と 実験値の一致は不可能と考える。ここで強調しなければ ならないのは固定電荷密度を一定とおき，移動度を変化 させることによって，計算値と奏験值の比較的よい一致 を見た点である。以上のようにして求めた有効荷電密度 と移動度の比を水中における移動度の比と共に表 1 に示

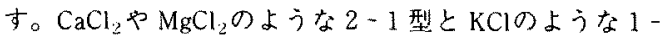

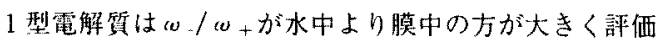
されており $\mathrm{MgSO}_{4} 、 \mathrm{~K}_{2} \mathrm{SO}_{4}, \mathrm{~K}_{2} \mathrm{HPO}_{4}$ の上うな2-2型や 1-2 型電解質は小さく評洒されている。

\section{2 荷電密度 [15] [16]}

ところで綃フィプロイン膜のような弱電解貿乘性荷電 膜における荷電密度 $\mathrm{C}_{\mathrm{x}}(\geqq 0)$ はそれぞれのアミノ酸に おける解離基の荷電密度の総和として表わすことが出来 る[17][18]。

$$
C_{x}=\left|-\Sigma_{i} \frac{K_{a} C_{x i}{ }^{0}(-)}{C_{11}+K_{a i}}+\sum \frac{C_{x i}{ }^{0}(+) C_{11}}{C_{11}+K_{b i}}\right|
$$

ここで $\mathrm{K}_{\mathrm{a} i}$ は酸性基の解離平衡定数， $\mathrm{K}_{\mathrm{bi}}$ は塭基性基 のプロトン解離平衡定数， $\mathrm{C}_{\mathrm{xi}}{ }^{0}($ 一)は固定酸性基密度, $\mathrm{C}_{\mathrm{xj}}{ }^{0}(+)$ は固定塩基性基密度， $\mathrm{C}_{\mathrm{H}}$ は水素1オン濃度で ある。等電点では $\mathrm{C}_{\mathrm{x}}=0$ となる。四 4 における金属塩 の濃度と $\mathrm{pH}$ との関倸を見ると、 $\mathrm{KCl}, \mathrm{MgSO}_{4}, \mathrm{MgCl}_{2}$, 
Table 1 Effective Fixed Charge Density $Q C_{x}$ and Ratio of Cation to Anion Mobillity $\omega_{-} / \omega_{+}$

\begin{tabular}{llccc}
\hline & $\begin{array}{c}\mathrm{QC}_{\mathrm{x}} \\
\mathrm{mol} / \mathrm{L}\end{array}$ & $\begin{array}{c}\omega_{-}{ }^{0} / \omega_{+}{ }^{0} \\
\text { (in water) }\end{array}$ & $\begin{array}{c}\omega_{-} / \omega_{+} \\
\text {(in membrane) }\end{array}$ & $\Phi$ \\
\hline $\mathrm{KCl}$ & 0.015 & 1.04 & 1.24 & 1.19 \\
$\mathrm{CaCl}_{2}$ & 0.015 & 2.57 & 4.0 & 1.56 \\
$\mathrm{MgCl}_{2}$ & 0.015 & 2.88 & 4.4 & 1.53 \\
$\mathrm{~K}_{2} \mathrm{SO}_{4}$ & 0.015 & 0.544 & 0.40 & 0.735 \\
$\mathrm{~K}_{2} \mathrm{HPO}_{4}$ & 0.015 & 0.388 & 0.32 & 0.825 \\
$\mathrm{MgSO}_{4}$ & 0.015 & 1.51 & 0.78 & 0.517 \\
\hline
\end{tabular}

$\mathrm{K}_{2} \mathrm{SO}_{4}$ に関しては pH の大きな变化はなく $\mathrm{pH}=5.7$ 付近 の值を取る。また $\mathrm{CaCl}_{2}$ に䦔しては濃慔の变化にともな い, 的 $\mathrm{pH}=5.5$ から約 $\mathrm{pH}=8.5$ まで変化する。これは

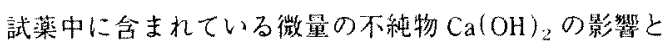
考えることができる。さらにK $\mathrm{K}_{2} \mathrm{HPO}$ 関してはリン 酸の第 2 塭の水溶液はアルカリ性であるため $\mathrm{pH}=8.0$ から $\mathrm{pH}=9.50$ 闑の值となった。そこで式10により各 $\mathrm{pH}$ における荷電密度を求めた。釈フイブロイン膜のア ミノ酸組成モル分率によるとアスパラギン酸0.97\%,グ ル夕ミン酸0.89\%，リジン0.23\%，アルギニン0.39\%， ヒスチジン0.15\%である[19]。アスパラギン酸及びグル タミン酸の側鎖のカルボキシル基, リジン側鎖の $E-ア$ ミノ基, アスバラギン側鎖のグアニジル基, ヒスチジン 側鎖のイミダゾール基が主として綟フィブロイン膜の荷 電基として存在している。徉ってこれらの解離平衡定数 はアスパラギン酸では $\mathrm{K}_{\text {a }}=1.38 \times 10^{-4}$ 、ダルタミン酸 では $\mathrm{K}_{\mathrm{a}}=5.62 \times 10^{-5}$, リジでは $\mathrm{K}_{\mathrm{b}}=2.95 \times 10^{-11}$, アルギニンでは $\mathrm{K}_{\mathrm{b}}=3.31 \times 10^{-13}$ ，七スチジンでは $\mathrm{K}_{\mathrm{b}}$ =1.07×106である。まずこ机らの值を使用して，式10 より $\mathrm{pH}=6.7 ， 8.7 ， 9.7 ， 10.16 お け る \mathrm{C}_{\mathrm{x}}$ を求めたと ころ，それぞれ0.304，0.309，0.309，0.309となり， $\mathrm{pH}$ の变化にもかかわらず大きな变化は見られなかっ た。従って膜電位の計算において， $\mathrm{pH} の$ 变化にもかか わらず有效荷電密度を一定と执いてカーブフィッティン

Table $2 \mathrm{pH}$ and Fixed Charge Density $\mathrm{C}_{\mathrm{x}}$

\begin{tabular}{ccc}
\hline & $\mathrm{pH}$ & $\mathrm{C}_{\mathrm{x}}$ \\
\hline $\mathrm{KCl}$ & 5.7 & 0.283 \\
$\mathrm{~K}_{2} \mathrm{SO}_{4}$ & 5.6 & 0.279 \\
$\mathrm{~K}_{2} \mathrm{HPO}_{4}$ & 9.0 & 0.309 \\
$\mathrm{MgSO}_{4}$ & 5.8 & 0.287 \\
$\mathrm{MgCl}_{2}$ & 5.8 & 0.284 \\
$\mathrm{CaCl}_{\mathrm{CaCl}_{2}}$ & 6.7 & 0.304 \\
& 8.5 & 0.309 \\
& 9.7 & 0.309 \\
& 10.1 & 0.309 \\
\hline
\end{tabular}

グを行っても大きな䜋差が見られないことを示唆してい 布

同様にして各金属塩溶液一膜系の $\mathrm{pH}$ の平均值を求 め，それぞれにおける荷電密投を計算した結果を表 2 に 示す。いずれの金属塩においても式100括弧の中は負の 值を取りここ $\mathrm{pH}$ 領域では膜が顛に荷電していること を示す。最小值は $\mathrm{K}_{2} \mathrm{SO}_{4}$ の時で $\mathrm{C}_{\mathrm{x}}=0.279$ ，最大值は $\mathrm{K}_{2} \mathrm{HPO}_{4}$ の時で $\mathrm{C}_{\mathrm{x}}=0.309$ であり, 荷電密度に大きな变 化は見られながった。ところで $\mathrm{KCl} の$ 場合アミノ酸の分 率から計算したC $\mathrm{x}$ が約0.283であり，膜電位の計算に よる有効荷電密度は $Q C_{x}=0.015$ と䄪 19 分の 1 程度の值 を取る。絹フイブロイン膜の結晶化度が約 $20 \%$ 程度であ るから結晶化による有効荷電基の減少によるとは考之る ことはできない。このような $\mathrm{C}_{\mathrm{x}}$ と $\mathrm{QC}$ 长吠きな違い を示す結果はすでにNーサクシニルキトサンでも報告さ れている。このことは正と負の再方の荷電基が混在して いるときは分配係数が大きくなる叮能性を示晙している と共に、イオンの移動に影翌を及ばす荷電基の数が見か け上著しく減少するものと考えることが出来る。

\section{3 移县度}

表1に示したように膜中におけるイオン移動度は水中 における值〔20]に比べて著しく变化することが明らかと なった。ところで表 1 に同時に水中の移動度比に対す

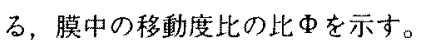

$$
\Phi=\frac{\omega_{-} / \omega_{+}}{\omega_{-} / \omega_{+}{ }^{0}}
$$

ここで $\omega_{-}{ }^{0}, \omega_{+}{ }^{\circ}$ は水中でのアニオン及びカチオンの 移動度である。

ところで小畠らはカチオン交換膜またはアニオン交換 膜中の移動度に関して固定荷電基と反対符号をもつイオ ンの移動度は副イオンと固定荷電密度の関数であること を示した[21-24]。

$$
\begin{aligned}
& \omega_{+}=\omega_{+}+\frac{C_{-}+\phi C_{x}{ }^{0}(-)}{C_{-}+C_{x}{ }^{0}(-)} \\
& \omega_{-}=\omega_{-}{ }^{0}
\end{aligned}
$$

ここで副イオンに関しては水中と同一の值を示すもの 
とする。C.は副イオンの濃度, $\mathrm{C}_{\mathrm{x}}{ }^{0}($ 一)は固定荷電密 度, $\phi$ は全固定荷電基のうち有效に作用する固定荷電基 の割合を表わすパラメータである。絹フィブロイン膜は 両性電解質であるから雨方のイオンに対して式12と同様 の取り扱いができると考える。また，固定荷電基が弱電 解質で南ることを考えると、式10を参考にしてカチオン とアニオンの両性荷電膜中ての移動度は次式とおくこと ができる。

$$
\begin{aligned}
& \omega_{+}=\omega_{+}^{0} \frac{\left|z_{-}\right| C_{-}+\sum \frac{\phi_{i} K_{a i} C_{x i}{ }^{11}(-)}{C_{11}+K_{a i}}}{\left|z_{-}\right| C_{-}+\Sigma \frac{K_{a 1} C_{x i}{ }^{0}{ }^{\prime}(-)}{C_{11}+K_{a i}}} \\
& \omega_{-}=\omega_{-}^{0} \frac{z_{+} C_{+}+\Sigma \frac{\phi_{j} C_{11} C_{i i}{ }^{0}(+)}{C_{11}+K_{b j}}}{z_{+} C_{+}+\Sigma \frac{C_{11} C_{x j}{ }^{0}(+)}{C_{11}+K_{b j}}}
\end{aligned}
$$

ここでぞ、ュ+はそれぞれアニオンとカチオンの洒数

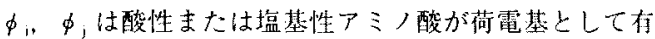
効に作用する程度を表加すパラメータである。

ところで式14，15簡単化して次式と㧍く

$$
\begin{aligned}
& \omega_{+}=\omega_{+}{ }^{0} \frac{\mid z-C+\phi(-) C_{\mathrm{x}}{ }^{n}(-)}{|z| C+C_{\mathrm{x}}{ }^{0}(-)} \\
& \omega_{-}=\omega_{-}^{0} \frac{z_{+} C_{+}+\phi(+) C_{\mathrm{x}}{ }^{0}(+)}{z_{+} C_{+}+C_{\mathrm{x}}{ }^{0}(+)}
\end{aligned}
$$

となる。ここで $\phi(+), \phi(-), \mathrm{C}_{\mathrm{x}}{ }^{\mathrm{O}}(-), \mathrm{C}_{\mathrm{x}}{ }^{0}(+)$ はそ

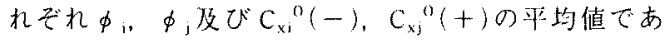
る。式16,17の比を取ると

$$
\begin{aligned}
\frac{\omega_{-}}{\omega_{+}} & =\frac{\omega^{\prime \prime}}{\omega_{+}{ }^{0}} \frac{\frac{z_{+} C_{+}+\phi(+) C_{x}{ }^{\prime \prime}(+)}{z_{+} C_{+}+C_{x}{ }^{\prime \prime}(+)}}{\frac{|z| C_{-}+\phi(-) C_{x}{ }^{\prime \prime}(-)}{|z| C+C_{x}{ }^{0}(-)}} \\
& =\frac{\omega_{+}{ }^{0}}{\omega_{+}{ }^{0}} \Phi
\end{aligned}
$$

ここでそれぞれのパラメータに頪フィブロイン膜がもつ 值に近い数值を代入してФの計算を陚みた。 $\phi(-)=\phi$ $(+)=1 / 15, \quad C_{x}{ }^{0}(-)=0.45, \quad C_{x}{ }^{1}(+)=0.15, \quad a=z+$ $\mathrm{C}_{+} / \mid$z- $\mid \mathrm{C}$-として, 異なった $\alpha$ に対して $\Phi z_{+} \mathrm{C}_{+}$の関 係图 6 に示す。ここで有効荷電密度の定義 $(\mathrm{QC}$ ) $)$ 及び

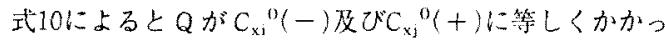

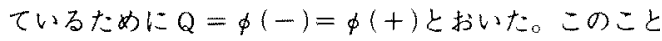
は固定荷電基が执互いに影響を及ほし合い，有効に作用 する固定荷電基の数が減少すると考えることもできる。 图6によるとФは $2+\mathrm{C}+$ と共に变化し，最大値または 最小値を持ち，Фを一定とする仮定と矛盾する。しかし このことを除ければ ๙が大きくなることは膜中のカチ才 ンの濃度がア二オンの濃度に比べて大きくなることを意

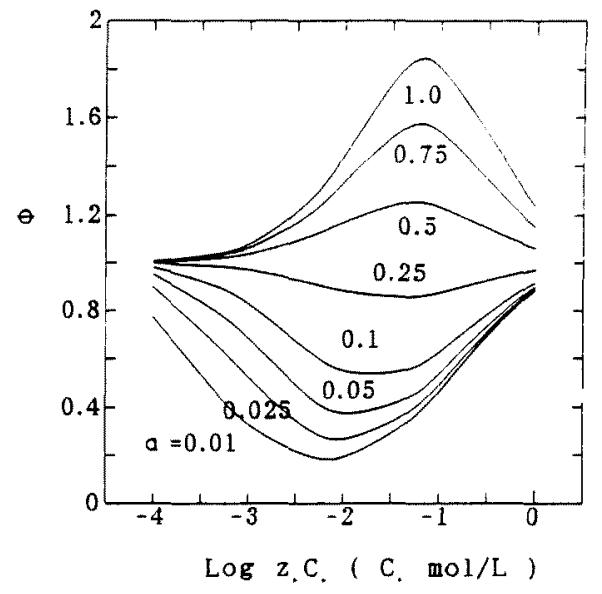

Fig. $6 \Phi$ as a function of cation concentration in the membrane.

味することから， $>1$ または $\Phi<1$ となる理由が膜中 に扔けるカチオンとアニオンの分仍淤部水溶液中とは 異なることにあることを示している $\mathrm{KCl}, \mathrm{MgCl}_{2}$ ， $\mathrm{CaCl}_{2}$ の場合は $\Phi>1$ となり、膜中にカチオンが多く分 配され、 $\mathrm{MgSO}_{4}, \mathrm{~K}_{2} \mathrm{SO}_{1} ， \mathrm{~K}_{2} \mathrm{HPO}_{4}$ の場合は $\Phi<1$ とな りアニオンのほうがより多く膜中に分配されることを示 唆している。いまここであは濃度及び $\mathrm{pH}$ 上らず一定と 执いている。このことはTMSの理論を適用するにあた り $\mathrm{Q}=$ 一定(即ち $\phi=一$ 定) と执けたことと, 同じアル カリ水溶液であっても $\mathrm{CaCl}_{2}$ の場合は $\Phi>1 ， \mathrm{~K}_{2} \mathrm{HPO}_{4}$ の場合は $\Phi<1$ となり本測定範囲では $\mathrm{pH} の$ 影旡を無視 できることによる。しかしながら本研究では実験結果に TMS 式を適用したところ高濃度側では耀密に一致して おらずまた $\mathrm{pH}$ の变化する䇿用も $\mathrm{pH} 5.5$ - 9.5 とアルカ リ側に偏っている。したがってめの塩浱度及び $\mathrm{pH} の$ 影 郘に対する検証にはQを塩㵏度の閣数としたTMS 式の 改良および膜電位の測定を酸側からアルカリ側まで広範 な領域にわたり行う必要がある。

\section{謝辞}

著者の一人，陳 建勇(中国浙江絲料工学院)は包 兆 龍，包王剛中国留学生桨学金のもとで本研究を行。 た。ここに包 兆龍, 包 玉剛中国留学生奖学金基金理 事会に深く感謝する。

\section{文献}

1，君㙇英夫，イ才ンの膜透過，共立出版，(1988）。

2. 山内 昭, 田中蜻子, 日本膜学会第14年会予稿集, 60 (1992). 
3. N. Minoura, M. Sieber, S. Motamedian and A. Tanioka Polymer Preprints, Japan, 41, 2706 (1992).

4. M. Demura, A. Kitamura, A. Shibamoto, and T. Asakura. J. Appl. Polym. Sci., 36, 535 (1988).

5. T.Teorell, Proc. Soc. Exptl. Biol., 33, 282 (1938).

6. K. H. Meyer and J. F. Sievers, Helv. Chim. Acta, 19. $649,665,987$ (1936).

7. 花井哲也，膜とイオン，化学同人，(1978).

8. 味沢昭義, 日虫雑, 38, 340 (1969).

9. 朝會哲郎, 中山信彦, 織学誌, 45, 252 (1989).

10. N. Minoura, M. Tsukada, and M. Nagura, Polymer. 31. 265(1990).

11. R. Schlogl, Stofftransport durch Membranen, Steinkopff, Darmstadt (1964).

12. 杉浦正昭，農化，47，9，263 (1973)。

13. M. Higa, A. Tanioka and K. Miyasaka, J. Membr. Sci. 37. 251 (1988).

14. M. Higa, A. Tanioka, and K. Miyasaka, J. Membr. Sci., 49. 145 (1990).
15. H. - U. Demisch and W. Pusch, J. Electrochem. Soc., 123, 370(1976).

16. H. - U. Demisch and W. Pusch. J. Colloid and Interface. Sci, 69, 247 (1979).

17. 真鍋 敬, 化学の領域，36，470（1982）。

18. 真鍋 敬, 新生化学実験講座 1 , タンパク質 $I$, p.336, 東京化学同人, (1990).

19. 桐村三郎, 絹系の構造, 74 , 伊藤武男編, 千曲会出 版社, (1957).

20. 日本化学会編，化学便覧 基礎編 II，3版，449, 丸善, (1984).

21. Y. Toyoshima, Y. Kobatake, and H. Fujita, Trans, Faraday Soc, 63, 2814 (1967).

22. Y. Toyoshima, M. Yuasa, Y. Kobatake, and H. Fujita, Trans. Faraday Soc., 63, 2803 (1967).

23. M. Yuasa, Y. Kobatake, and H. Fujita, J. Phys. Chem., 722871 (1968).

24. 加茂直樹，小畠陽之助，生物物理，11，23(1971). 